\title{
UNSUR BUDAYA MINANGKABAU DALAM NOVEL MENCARI CINTA YANG HILANG KARYA ABDULKARIM KHIARATULLAH
}

\author{
Diah Irawati \\ diahirawati_dhyra@yahoo.com
}

\begin{abstract}
This research aims to describe (1) function of "maternal uncle" for his nephew (2) prohibition for the same tribe marriage (3) the function of maternal uncles for people in one tribe including in Novel "Mencari cinta yang Hilang" by Abdulkarim Khiaratullah. This research was qualitative research that used descriptive methode which had characteristic was conten analysis, that is a research which have done by examining a literature manuscript by looking at a piece of fact or dialog from the figure that purpose to knowing the element of minangkabau culture that including in novel. Technique of gathering data in this research use documentation technique and writing a note technique. Analysis result show that, first, in overal 'maternal uncle' describing in this novel is responsive and guiding his nephew, its according to rules, which 'maternal uncle' in Minangkabau People is very important to his nephew life. Only 'maternal uncle' from Rahima, Mak Katik which did not a right job. Second, problem about forbidding one tribe marriage is still a trouble on Minangkabau people life, that is reflected in novel that still find a polemic about forbidding one tribe wedding, tradition agreement which very compoting with one tribe marriage whom judging as marriage with own family, in other hand based on religion one tribe marriage is not forbidden thing. Third, this novel also reflect a figure of 'Niniak Mamak' in minangkabau people, there is finish tradition clash, in this novel 'niniak mamak' also finish a problem of one tribe marriage, which is Chaniago clan, on discussion which leading by Datuk Rangkayo Sati as people leader has a decision which a one tribe marriage between Fauzi and Rahima can not continued.
\end{abstract}

Key Word : Minangkabau culture, maternal uncle, maternal uncle's, the same tribe marriage, novel

\section{Pendahuluan}

Membicarakan masalah sastra memang tidak terlepas dari manusia karena manusia yang menjadi subjek dan objek di dalam sastra. Semi (1988:8) mengemukakan bahwa sastra itu merupakan suatu bentuk dan hasil pekerjaan seni kreatif yang objeknya adalah manusia dan kehidupannya dengan menggunakan bahasa sebagai medianya. Sebagai seni kreatif yang menggunakan manusia dan segala macam segi kehidupannya maka ia tidak saja menggunakan suatu media untuk menyampaikan ide, teori, atau sistem berfikir manusia. Dengan demikian dalam sastra terdapat tiga komponen yang saling berhubungan yaitu sastra sebagai seni kreatif, objeknya manusia dan kehidupannya, dan mengunakan bahasa sebagai medianya.

Karya sastra juga dikenal sebagai dokumentasi budaya. Karya sastra lahir dari budaya tertentu. Dapat dikatakan juga suatu karya sastra lahir atas dorongan dari kebudayaan yang berlaku dalam suatu kelompok masyarakat. Budaya tersebut hidup dan berkembang di tengah-tengah masyarakat, diolah melalui fakta imajinatif. Budaya menyangkut perilaku, sikap dan gagasan. Menurut Endraswara (2011:192), realitasnya, batas antara sastra, budaya dan seni hampir sulit dipisahkan. 
Ketiganya memuat segala angan-angan, sikap hidup dan perilaku manusia.

Kebudayaan adalah seluruh sistem gagasan, rasa, tindakan, serta karya yang dihasilkan manusia dalam kehidupan bermasyarakat, yang dijadikan miliknya dengan belajar. Dengan demikian hampir semua tindakan manusia adalah "kebudayaan". (Koentjaraningrat, 2011:72-73). Hal serupa juga dikemukakan oleh Ratna (2011:393) yaitu semua bentuk karya manusia dapat dimasukkan sebagai kebudayaan, hampir semua ilmu pengetahuan, baik momotetis, maupun ideografis membicarakan masalahmasalah kebudayaan sehingga segala sesuatu dapat dijelaskan melalui kebudayaan.

Suatu kebudayaan menandakan adanya proses berfikir yang dilandasi semangat hidup dan tersimpul dalam pandangan hidup yang dilatarbelakangi oleh lingkungan dan kepercayaan yang dianut suatu masyarakat. Pandangan itu akan mengungkapkan bagaimana manusia mencapai hakiki hidup, kedudukan yang layak di tengah-tengah manusia lain serta menunaikan kewajiban lain terhadap Tuhan. Semua itu tercermin dari hasil kebudayaan yang ada, dalam hal ini adalah seni sastra. (Koenjaraningrat, 2004:29). Menganalisis suatu karya sastra dengan sendirinya juga menganalis masalah-masalah kebudayaan yang ada di dalamnya. Untuk lebih memfokuskan koenjaraningrat juga membagi unsur kebudayaan menjadi tujuh bagian pokok yaitu sistem religi, sistem bahasa, sistem peralatan dan perlengkapan hidup, sistem mata pencaharian,sistem pengetahuan, sistem kemasyarakatan (kekerabatan dan organisasi sosial) dan sistem kesenian.

Menurut Ratna (2011:405) dalam karya sastra masalah yang paling banyak diungkapkan adalah sistem kemasyarakatan terutama sistem kekerabatan dengan berbagai implikasinya. sistem kekerabatan melibatkan sistem komunikasi dari kelompok manusia yang paling kecil, sebagai tatap muka hingga kelompok yang paling besar, sebagai masyarakat itu sendiri. Kelompok kecil dalam hubungan ini juga termasuk hubungan suami istri, sebagai keluarga inti, melaluinya akan berkembang model hubungan kekerabatan lain yang lebih luas. Model hubungan inilah yang mendasari mekanisme penyusunan cerita dalam berbagai bentuknya.

Berbicara mengenai karya sastra, maka bentuk karya sastra yang paling terkenal dewasa ini adalah novel dan cerpen (Semi, 1998:32). Menurut Damono (1979:71) novel merupakan karya sastra yang berkembang dengan baik di Indonesia. Di dalam novel pengarang memberikan alternatif pada manusia untuk menyikapi hidup dan kehidupan manusia melalui tokoh-tokoh yang telah ditentukan oleh pengarang.

Banyak novel yang lahir berlatarkan kebudayaan. Salah satunya yaitu budaya Minangkabau. Masalah adat istiadat Minangkabau masih terus menjadi pembicaraan, terbukti dengan banyaknya novel baru yang masih mengangkat tema tentang adat istiadat minangkabau, salah satunya adalah novel Mencari Cinta yang Hilang karta Abdulkarim Khiaratullah (Penerbit, Diva Press).

Novel ini mengandung ajaran dan nilai-nilai yang memang patut dipahami, 
terutama pandangan berbeda atau sebuah protes terhadap aturan adat Minangkabau yang masih berlaku hingga saat ini. Novel ini menceritakan menggambarkan unsur-unsur budaya yang berlaku dalam kehidupan masyrakat Minangkabau, khususnya sistem kekerabatan. Mengisahkan kehidupan tokoh Fauzi, yang telah ditinggal ayahnya sejak kecil. la hidup bersama ibunya, dan dibiayai oleh mamaknya dari hasil toko pakaian peninggalan ayahnya yang sekarang diolah seutuhnya oleh Mak Pito. Hingga kisahnya menuntut ilmu ke timur tengah, dan dijodohkan oleh tetangga yang sudah seperti keluarga sendiri. Jodoh pilihan ibunya yaitu Rohima, anak dari ayah angkatnya yang juga merupakan tetangganya. Perjodohan ini lah yang menjadi puncak penceritaan, di mana suku Fauzi dan Rohima sama, yaitu Chaniago. Hal ini sangat ditentang dalam adat Minangkabau. Pernikahan sesuku bagi masyarakat minangkabau merupakan sesuatu yang sangat dilarang.

Berdasarkan uraian di atas, Novel Mencari Cinta yang Hilang karya Abdulkarim Khiaratullah ini menarik untuk diteliti, karena sebagai generasi muda, Abdulkarim Khiaratulah tertarik untuk mengangkat masalah kebudayaan terutama kebudayaannya sendiri, dan mengajak para pembaca merenungkan kembali kebudayaan yang selama ini dipakai di dalam masyarakat. Dalam hal ini lebih difokuskan pada salah satu unsur kebudayaan yaitu sistem kekerabatan khususnya peran mamak, niniak mamak dan juga mengenai pernikahan sesuku yang sebenarnya tidak dilarang oleh agama. la menekankan kembali kepada pembaca,
"Bukankah adat Minangkabau bersandikan syara' sedangkan syara' bersandikan pada kitabullah? Jadi sesuatu yang sesuai dengan Al-Quran berarti sesuai dengan adat. Jadi

Mamak merupakan sebutan untuk saudara laki-laki ibu, dalam masyarakat Minangkabau mamak memiliki peran seperti peran seorang Ayah terhadap anaknya. Mamak bertanggungjawab terhadap kehidupan keponakannya. Seperti falsafah Minangkabau anak dipangku kemenakan dibimbing yang artinya anak dipangku keponakan dibimbing. Mamak juga bertanggungjawab penuh terhadap pernikahan keponakannya, apabila tidak bisa diselesaikan oleh mamak maka permasalahan biasanya dilimpahkan kepada niniak mamak. Permasalahannya, menurut pengamatan penulis saat ini kedudukan mamak dalam kehiduapan masyarakat Minangkabau sudah mulai bergeser. Seorang mamak yang seharusnya memiliki peranan yang cukup penting bagi kehidupan keponakannya sudah jarang sekali terjadi, seorang mamak lebih peduli kepada anaknya sendiri, dan terkadang ada juga yang tidak peduli dengan keponakannya.

Niniak mamak merupakan gabungan antara mamak-mamak dalam suatu keluarga yang bertugas terhadap kaumnya, kaum dalam masyarakat Minangkabau yaitu kumpulan masyarakat yang memiliki suku yang sama, mamak berfungsi untuk menyelesaikan sengketa atau permasalahan dalam kaumnya. Niniak mamak diketuai oleh penghulu, yang diberi gelar Datuk. Fenomena saat ini, posisi niniak mamak juga sudah mulai berubah. Banyak niniak mamak yang bersikap tidak adil, yang membedakan 
kemenakan yang kaya dan yang kurang berada.

Syarat pernikahan menurut agama islam yang paling mutlak, yaitu seiman dan tidak memiliki hubungan darah. Sedangkan dalam masyarakat Minangkabau terdapat aturan mutlak lain yaitu tidak susuku. Menurut Navis (1986:195) perkawinan pantang ialah perkawinan yang akan merusak sistem adat mereka, yaitu perkawinan orang yang setali darah menurut stelsel matrilineal, sekaum dan juga sesuku mekipun tidak ada hubungan kekerabatan dan tidak sekampung halaman.

Permasalahan pernikahan sesuku merupakan problema klasik yang sampai saat ini masih menuai kontroversi. Suatu aturan yang bisa membuat seseorang diusir dari kampung dan dikeluarkan dari keluarga besar apabila dilanggar.

Karya sastra sebagai dokumentasi budaya tentulah dapat merefleksikan budaya itu sendiri. Penelitian peranan mamak terhadap kemenakan, peranan niniak mamak terhadap masyarakat sesuku dan larangan pernikahan sesuku belum banyak diteliti dalam karya sastra. Oleh sebab itu, perlu dilakukannnya penelitian ini agar dapat memperoleh gambaran adat yang berlaku dalam masyarakat Minangkabau baik dalam novel maupun dalam masyarakat. Penelitian ini juga diharapkan mampu menarik simpati generasi muda untuk mempelajarinya sebagai wujud kepedulian terhadap suatu budaya khususnya budaya Minangkabau, terutama yang terkandung dalam novel Mencari Cinta yang Hilang karya Abdulkarim Khairatullah.

\section{METODE PENELITIAN}

Jenis penelitian ini merupakan penelitian kualitatif. Moleong (2010:6) menjelaskan penelitian kualitatif adalah penelitian yang bermaksud untuk memahami fenomena tentang apa yang dialami oleh subjek penelitian misalnya perilaku, persepsi, motivasi, tindakan dan lain-lain secara holistik dan dengan cara deskripsi dalam bentuk kata-kata dan bahasa, pada suatu konteks khusus yang alamiah dan memanfaatkan berbagai metode ilmiah.

Metode yang digunakan yaitu metode deskriptif. Metode deskriptif yang bersifat content analysis (analisis isi), yaitu penelitian yang dilakukan dengan menelaah sebuah karya sastra dan bertujuan untuk mendeskripsikan realitas peranan mamak, larangan perkawinan sesuku masyarakat Minagkabau, dan peranan niniak mamak yang ada dalam novel Mencari Cinta yang Hilang karya Abdulkarim Khiaratullah. Penelitian ini pun dilakukan untuk menganalisis isi dan memberi makna terhadap novel ini terutama mendeskripsikan budaya Minangkabau yang terurai dalam bentuk kata-kata, bukan dalam bentuk angka-angka.

Data penelitian ini adalah kata, frase, kalimat maupun paragraf yang berhubungan dengan peranan mamak, peranan niniak mamak dan larangan pernikahan sesuku masyarakat Minangkabau. Sumber data penelitian ini adalah novel Mencari Cinta yang Hilang karya Abdulkarim Khiaratullah, terbitan DIVA Press cetakan pertama Juni 2012, setebal 392 halaman.

Teknik pengumpulan data yang digunakan dalam penelitian ini adalah: 
1. Teknik dokumentasi

Menurut Hikmat (2011: 83) teknik dokumentasi adalah pelusuran dan perolehan data yang diperlukan melalui data yang telah tersedia. Dokumen merupakan catatan peristiwa yang sudah berlalu. Dokumen bisa berbentuk gambar, karya-karya monumental dari seseorang, atau tulisan/ teks (misalnya: novel, cerpen, puisi, dan lain-lain). Dalam penelitian yang akan dilakukan ini, dokumentasinya berupa novel yang akan dianalisis yaitu novel Mencari Cinta yang Hilang.

2. Teknik catat

Menurut Muhammad (2011:

211), teknik catat adalah pencatatan yang dilakukan pada kartu data yang telah disediakan atau akan disediakan. Catatan dibuat dalam bentuk kata-kata kunci, singkatan, pokok-pokok utama saja, kemudian dilengkapi dan disempurnakan pada tahap analisis nanti. Muhammad menyatakan ada kiat dalam mencatat data, yaitu garis bawahi, cetak tebal, dan cetak miring. Dalam penelitian ini, teknik yang digunakan yaitu dengan cara menggarisbawahi data-data yang dianggap perlu dalam novel Mencari Cinta yang Hilang karya Abdulkarim Khiaratullah setelah itu baru memindahkan ke tabel yang telah disiapkan sebagai instrumen penelitian. Lincolh (dalam Moleong, 2013: 216) dokumen ialah setiap bahan tertulis ataupun film. Dari pengertian tersebut, dapat disimpulakan bahwa teknik dokumentasi yang digunakan dalam penelitian ini yaitu dengan mencatat dan mengumpulkan seluruh temuan dari novel yang sesuai dengan masalah yang akan diteliti dengan bantuan daftar dan tabel data.
Untuk mempermudah proses penelitian digunakan Instrumen penelitian dalam bentuk format pencatatan data. Peneliti membaca, mencatat, memahami, menghayati, mengidentifikasi dari bentuk-bentuk realitas perkawinan sesuku masyarakat Minangkabau dalam novel Mencari Cinta yang Hilang karya Abdulkarim Khiaratullah dengan menggunakan tabel inventarisasi data. Data tersebut tentang perilaku tokoh dalam novel Mencari Cinta yang Hilang karya Abdulkarim Khiaratullah diinventarisasi secermatcermatnya.

Analisis data dalam penelitian ini dilakukan dengan cara kualitatif dengan langkah-langkah sebagai berikut:

1. Membaca teks novel Mencari Cinta yang Hilang karya Abdulkarim Khiaratullah.Membuat tabulasi data yang berhubungan dengan peranan mamak dan pernikahan sesuku dalam novel Mencari Cinta yang Hilang karya Abdulkarim Khiaratullah.

2. Mengklasifikasi hasil tabulasi terhadap peranan mamak dan pernikahan sesuku dalam novel Mencari Cinta yang Hilang karya Abdulkarim Khiaratullah.

3. Menginterpretasikan data didasarkan peranan mamak dan pernikahan sesuku dalam novel Mencari Cinta yang Hilang karya Abdulkarim Khiaratullah.

4. Penyajian data hasil penelitian mengenai peranan mamak dan pernikahan sesuku dalam novel Mencari Cinta yang Hilang karya Abdulkarim Khiaratullah.

5. Menarik kesimpulan dari hasil penelitian. 


\section{Pembahasan}

Tali kekerabatan mamak dan kemenakan merupakan hubungan antara seorang anak laki-laki dan saudara lakilaki ibunya, atau hubungan seorang lakilaki dengan anak-anak saudara perempuannya. Berhubung mamak merupakan fungsi laki-laki, maka hubungan mamak dengan kemenakan adalah hubungan yang memerankan tanggung jawab terhadap kewajiban. Kewajiban mamak di Minangkabau sama atau bahkan melebihi tugas seorang ayah pada masyarakat non Minangkabau. Berbeda dengan ayah seorang mamak akan berhadapan lebih banyak kemenakan jika mamak itu banyak saudara perempuannya (Navis, 1986:233).

Budaya Minangkabau menganut sistem matrilineal, yaitu garis keturunan diambil dari garis Ibu. Dari sistem ini, masyarakat Minangkabau menggunakan nama suku yang diambil dari suku Ibunya sebagai penanda suatu kaum. Penataan sistem ini menempatkan mamak yaitu saudara laki-laki ibu sebagai penentu keputusan dari suatu rumah gadang. Dalam arti luas mamak adalah semua kaum laki-laki. Sedangkan kemenakan adalah anak dari saudara perempuan, dapat juga diartikan anak dari saudara perempuan yang sepersukuan. Seorang mamak adalah pemimpin terhadap kemenakannya.

Seorang mamak merupakan pemimpin terhadap kemenakannya. Dalam suatu rumah gadang, dipilih satu mamak yang diangkat menjadi penghulu dengan gelar Datuk. Seperti dalam pepatah minang berikut ini, kemenakan beraja kepada mamak, mamak baraja kepada penghulu, penghulu beraja kepada musyawarah, musyawarah beraja kepada alur dan patut yang artinya seorang keponakan belajar kepada mamaknya, seorang mamak belajar kepada penghulunya, datuk belajar kepada musyawarah, musyawarah beraja kepada alur dan ketentuan.

Berdasarkan paparan di atas, baik buruknya seorang kemenakan ditentukan oleh kepemimpinan mamaknya dan juga penghulunya. Kemenakan menyandarkan nasibnya kepada mamak dan juga Mamak wajib untuk membimbing keponakannya demi kemajuan dan perbaikan nasib kemenakannya. Mamak, diharapkan mampu mencari jalan keluar bila ada persoalan yang dialami oleh kemenakan dan anggota kerabatnya. Tetapi tentu saja ada juga mamak yang tidak bisa ditaati karena tidak bijaksana dalam memimpin dan hanya mementingkan diri sendiri. Seorang mamak merupakan pusat dan inti dari sistem matrilineal dan rumah gadang sebagai basis tempat tinggal anggota keluarga secara meluas. Di sebuah rumah gadang inilah, eksistensi seorang mamak akan diakui oleh semua anggota keluarga. Semua aktivitas yang berhubungan dengan rumah gadang harus melibatkan mamak. Dapat disimpulkan lelaki Minangkabau memiliki dua peran, yaitu sebagai seorang Ayah dari anak-anaknya dan juga sebagai seorang Mamak dari kemenakannya. Seorang leleaki Minangkabau selain bertanggung jawab kepada anaknya juga wajib bertanggungjawab kepada keponakannya. Posisi anak dan kemenakan bagi laki-laki Minangkabau yaitu Anak di pangku kemenakan dibimbing yang artinya anak dipangku, keponakan dibimbing. 
Dalam novel Mencari Cinta yang Hilang karya Abdulkarim Khiaratullah ini mencerminkan peran mamak pada masyarakat Minangkabau. Secara keseluruhan peranan mamak dalam novel ini sudah berjalan sebagai mana mestinya. Mak Palito merupakan mamak dari Fauzi, di sini peran Mak Palito yaitu mamak yang sangat bertanggung jawab kepada kemenakannya. Sejak Ayah Fauzi meninggal dunia, kehidupan Fauzi dan Ibunya dibantu oleh Mak Palito, Mak Palito membantu meneruskan usaha dari Ayah Fauzi, bahkan di tangan Mak Palito usaha tersebut semakin maju. Impian Fauzi untuk melanjutkan pendidikan ke negeri Arab pun disetujui oleh Mak Palito, sebagai Mamak yang bertanggung jawab, Mak Palito bernegosiasi untuk menjual sebidang tanah warisan keluarga untuk menanggung biaya pendidikan Fauzi di Arab nanti. Gambaran Mak Palito sebagai mamak memang mencerminkan peranan mamak yang seharusnya di Minangkabau. Mamak yang mengayomi keponakannya, kesejahteraan keponakannya, bahkan Mak Palito juga sangat mendukung keponakannya.

Selanjutnya mengenai peranan niniak mamak terhadap kaum atau masyarakat sesuku dalam novel ini sudah menggambarkan peranan niniak mamak seperti seharusnya. Menurut Navis (1986:223) tali kerabat antara mamak dan kemenakan merupakan tali kerabat yang ditumbuhkan bagi keperluan kesinambungan dan kestabilan kepemimpinan di lingkungan sosial, sejak dari rumah, kampung sampai ke nagari. Fungsi kepemimpinan itu pada tingkat yang lebih tinggi dan yang lebih luas disebut penghulu.
Dalam novel ini, menggambarkan permasalahan yang tidak bisa diputuskan oleh mamak saja, tetapi harus diselesaikan dengan niniak mamak. Sesuai dengan fungsinya, niniak mamak berkewajiban menyelesaikan permasalahan yang berhubungan dengan nama baik suku atau kaumnya. niniak mamak melaksanakan rapat atau musyawarah di Balai adat untuk memutuskan perkara yang menimpa keponakannya. Permasalahannya dalam novel ini yaitu pernikahan sesuku, sehingga kedua belah pihak memiliki penghulu yang sama yaitu Datuk Rangkayo Sati.Dalam novel ini, menggambarkan permasalahan yang tidak bisa diputuskan oleh mamak saja, tetapi harus diselesaikan dengan niniak mamak. Peranan niniak mamak secara keseluruhan juga sudah berjalan dengan baik. Misalnya pada kasus Fauzi yang telah terlanjur melaksanakan pertunangan dengan Rahima yang memilki suku yang sama dengannya. Mak Palito sebagai mamak Fauzi tidak bisa memutuskan hal yang sangat ditentang oleh adat ini secara sepihak. Mak Palito memintak pendapat dari niniak mamak. Tidak sampai disana keputusan juga tidak bisa diambil dari niniak mamak Fauzi saja, tetapi harus ada rundingan dari niniak mamak kedua belah pihak.

Dalam novel ini juga memberikan penjelasan mengenai suasana rapat niniak mamak ketika melakukan rapat atau musyawarah di Balai adat untuk memutuskan perkara yang menimpa keponakannya. Permasalahannya dalam novel ini yaitu pernikahan sesuku, sehingga kedua belah pihak memiliki penghulu yang sama yaitu Datuk Rangkayo Sati. 
Rapat ini dihadiri oleh Mamakmamak dari Fauzi dan juga Rahima. Dari pihak Fauzi yaitu Mak palito dan Mak Ujang, dari pihak Rahima hadir Mak Katik, Mak Pakiah dan Mak Lelo. Dalam Rapat ini lah permasalahan di angkat, dan setiap orang berhak mengeluarkan pendapat berdasarkan pandangan masing-masing. Seperti Mak Katik yang sangat menentang pertunangan keduanya. Ada juga Mak Lelo dan Mak Pakiah yang lebih bijaksana yang masih meminimkan kemudharatan dari permasalahan ini. Mak Palito tetap saja, merupakan Mamak yang bijaksana, yang lebih memandang dari kedua sisi, baik agama maupun adat. Setelah semuanya mengeluarkan pendapat, barulah penghulu yaitu Datuk Rangkayo Sati yang menyimpulkan dan mengambil keputusan.

Keputusan yang diambil penghulu tidak bisa diganggu gugat lagi. Semua yang hadir di rapat harus menyetujinya. Karena penghulu merupakan orang nomor satu disuatu kaum. Pemilihan seorang Datuk juga tidak mudah, melalui proses dan kesepakatan bersama, seorang Datuk harus merupakan orang yang cerdas, yang sangat paham dengan adat. Dalam novel ini, keputusan Datuk Sati yaitu membatalkan pernikahan. Jadi pernikahan tidak bisa dilanjutkan. Keputusan Datuk Sati juga diterima oleh semua yang hadir, meskipun Fauzi dan Rahima sangat kecewa terhadap keputusan mamaknya. Tetapi karena menghormati keputusan niniak mamak fauzi rela pernikahannya dengan Rahima dibatalkan.

Dalam novel ini juga, menggambarkan seorang mamak yang mementingkan diri sendiri. Seperti Mak Katik, Mak Katik adalah orang yang paling menentang pernikahan Fauzi dan Rahima. Ternyata, Mak Katik melakukan semua ini karena ingin menjadikan Rahima sebagai menantunya. Agung anak dari Mak Katik menyukai Rahima, sehingga ia meminta Ayahnya untuk meminang Rahima. Hal ini tentu saja melenceng dari peran mamak yang seharusnya. Karena Mak Katik lebih mengutamakan keinginan anaknya dari pada kebahagiaan kemenakannya.

Pada kenyataannya, memang peranan mamak sudah mulai bergeser, sebagian mamak hanya mementingkan urusan rumah tangganya saja, tanpa memperdulikan kemenakannya. Mamakkemenakan dibimbing anak dipangku sudah jarang digunakan lagi. Mamak hanya tinggal mamak. Bahkan banyak mamak yang rela menjual harta pusaka, dan lain-lain.

Selanjutnya akan dibahas mengenai pernikahan sesuku dalam masyarakat Minangkabau. Pernikahan sesuku merupakan pernikahan yang sangat dilarang oleh masyarakat Minangkabau. Pernikahan sesuku terus menjadi polemik dalam masyarakat Minangkabau. Adat basandi syara', syara' basandi kitabullah yang merupakan falsafah Minangkabau yang membuat salah satu penyebab pertentangan dalam permasalahan ini.

Adat bersendi syariat, sedangkan syariat bersendikan Al-Quran, sehingga sesuatu yang dibuat oleh adat itu tumpang tindih dengan Al-Quran. Pernikahan sesuku, dilarang karena dianggap menikah dengan saudara sendiri, padahal sesuku bukan berarti memiliki pertalian darah. Sedangkan pernikahan yang yang dilarang oleh agama yaitu pernikahan yang memiliki pertalian darah. 
Larangan pernikahan sesuku dianggap hablum minanas, agar tidak terjadi pergunjingan di kampung. Paradigma masyarakat akibat dari pernikahan sesuku yaitu siap-siap akan menjadi bahan cemoohan orang satu kampung dan juga jika tetap dilakukan rumah tangga diprediksi tidak akan membentuk keluarga yang sakinah, mawadah dan warahma, diprediksi tidak akan memiliki keturunan, kalaupun ada akan memiliki anak yang cacat mental maupun cacat fisik karena dianggap memiliki genetika yang sama. Selain itu juga memilki anak yang berkelakuan buruk, dan juga mereka yang kawin sesuku dianggap sebagai pelopor kerusakan hubungan dalam kaumnya. Apabila seseorang merani melakukan pernikahan sesuku, konsekuensinya yaitu di usir dari kampung dan dikeluarkan dari keluarga besar. hal ini tentu saja merupakan sesuatu yang harus di hindari.

Dalam novel Mencari Cinta yang Hilang karya Abdulkarim Khiaratullah ini mengangkat masalah pernikahan sesuku. Pernikahan yang dianggap sesuatu yang sangat tabu dan harus dihindari. Di sini, mengisahkan tentang orang yang mendalami ibu agama ingin menikahi wanita yang memiliki suku yang sama dengannya. Polemik ini dimulai ketika Pak Zaidan menyusul Fauzi ke Arab di samping untuk menunaikan ibadah kepada Allah. Pak Zaidan melamar Fauzi untuk dijadikan menantunya dengan menikahi Rahima putrid pertamanya. Fauzi sebenarnya sangat terkejut karena ia tahu bahwa ia dan Rahima memiliki suku yang sama. Tetapi sebagai orang yang mendalami agama, Fauzi tidak menemukan kesalahan dari segi agama. Di tambah lagi Fauzi memang sejak dulu menyukai Rahima. Fauzi dan Rahima berdekatan rumah, sejak kecil rahima dan Fauzi sudah sering bergaul dan main bersama, Rahima dan adik-adiknya sudah seperti saudara bagi Fauzi. Selama Fauzi menempuh pendidikan Rahima dan keluarganya lah yang turut menjaga Ibu Fauzi.

Pak Zaidan dan Ibu Fauzi lebih memandang dari segi agama, karena antara Fauzi dan Rahima tidak terdapat pertalian darah. Sedangkan hubungan keluarga sangat dekat, jadi meraka ingin mendekatkan lagi kekeluargaan ini dengan menikahkan keduanya. Setelah kepulangannya ke Indonesia, barulah masalah ini di angkat dengan mamak masing-masing. Sesuai dengan aturan pernikahan sesuku pada umumnya, pernikahan mereka berdua juga mengalami masalah. Sehingga harus diadakan rapat di Balai Adat yang dihadiri masing-masing pihak. Rapat niniak mamak ini berlangsung rumit.

Tentu sada dalam musyawarah terdapat pro dan kontra, dalam novel ini mencerminkan realitas yang terjadi pada masyarakat minangkabau tentang perbedaan pandangan antara agama dan adat. Yang menyetujui pernikahan tentu saja dengan berlandaskan agama, bahwa antara Fauzi dan Rahima tidak memiliki pertalian darah. Dan juga larangan pernikahan sesuku juga sudah tidak bisa dipakai lagi pada kondisi saat ini.

Dalam novel ini berpendapat, mungkin saja larangan pernikahan sesuku dilakukan karena dulu masyarakat Minangkabau masih sangat sedikit sehingga untuk membedakan hubungan persaudaraan ditandai dengan suku. Tetapi sekarang penduduk Minangkabau sudah jutaan. Sehingga 
belum tentu memiliki suku yang sama berarti memilki pertalian darah.

Dalam novel ini juga memberikan solusi, jika saja pernikahan ini terus dilakukan, bisa dengan membayar denda yaitu menyembelih seekor kerbau untuk dipersembahkan kepada niniak mamak atau keluar dari kampung. Alasan dari niniak mamak yang melarang pernikahan sesuku dalam novel ini sama dengan kenyataan yang berlaku di Masyarakat Minangkabau, yaitu menikah sesuku adalah menikahi saudara sendiri, ia memegang dalil Al-Quran surat An-nissa yaitu dilarang menikah dengan saudara sendiri. Padahal jika dikaji, saudara seperti apa yang dimaksud, yaitu saudara yang memilki pertalian darah, itu jugalah alasan yang dibahas di novel ini.

Keputusan final dari novel dengan alasan meminimalkan kemudharatan yaitu, pertunangan harus dibatalkan karena apabila dilanjutkan akan menjadi gunjingan orang-orang kampung, akan mencoreng suku Chaniago, dan perkataan niniak mamak Caniago tidak akan didengar lagi dalam musyawarah kampung. Kepatuhan terhadap aturan adat tetap dilaksanakan, karena meskipun melaksanakan solusi yaitu dengan menyembelih kerbau atau keluar dari kampung tetap saja mencoreng kaum Chaniago. Sehingga penghulu memutuskan untuk tidak melaksanakan pernikahan.

Dampak dari pembatalan pernikahan sesuku dalam novel ini malah menjadi malapetaka. Fauzi akhirnya pergi menenangkan diri ke Jakarta. Sedangkan Rahima dinikahkan dengan anak mamaknya yaitu Agung, anak dari Mak Katik. Karena kepedihan hatinya yang sangat mencintai Fauzi, akhirnya Rahima sakit-sakitan hingga meninggal dunia. Ternyata Mak Katik yang sangat menentang pernikahan keduanya, meskipun ada solusi yang diberikan oleh adat memiliki maksud terselubung yaitu ingin menikahkan anaknya dengan Rahima.

Jika kita hubungkan dengan kenyataan sekarang, pernikahan sesuku mamang tetap menjadi sesuatu yang tabu dan juga dilarang oleh agama. Tetapi sudah banyak solusinya, selain solusi yang sudah dikemukakan dalam novel Mencari Cinta yang Hilang karya Abdulkarim Khiaratullah yaitu keluar dari kampung atau menyembelih kerbau, ada solusi lagi yang bisa diberlakukan yaitu keluar dari suku dan mengaku mamak dan suku lain di luar daerahnya dengan kosekuensi seluruh haknya di rumah gadang habis.

\section{Simpulan}

Berdasarkan hasil penelitian dan pembahasan dapat disimpulkan bahwa:

1. Peranan mamak terhadap kemenakan yang digambarkan dalam novel ini, menggambarkan peranan mamak yang sudah sesuai dengan kenyataan, yaitu ada mamak yang berperan seperti seharusnya yang bertanggung jawab penuh kepada kemenakannya yaitu Mak Palito, mamak dari Fauzi. Dan juga digambarkan watak mamak yang lebih mengutamakan anaknya dari pada kemenakan seperti mamak dari Rahima yaitu Mak Katik.

2. Larangan pernikahan sesuku dari segi agama dan adat. Dari segi agama yang sebenarnya bukan menjadi suatu masalah, sedangkan dari adat yang dianggap sangat menimbulkan masalah yaitu mempermalukan kaum karena dianggapp menikah dengan 
saudara sendiri. Novel ini lebih menggambarkan betapa kuatnya adat Meskipun ada solusi yang dibisa dilakukan yaitu keluar dari kampung atau menyembelih kerbau untuk dipersembahkan kepada niniak mamak.

3. Peranan niniak mamak terhadap kaum atau masyarakat sesuku dalam novel ini juga menggambarkan realitas yang terjadi di masyarakat Minangkabau. Niniak mamak bertanggung jawab terhadap permasalahan yang menimpa kaumnya, dalam hal ini pernikahan sesuku.

\section{Saran}

Berdasarkan hasil penelitian dan kesimpulan, ada beberapa saran yang dapat diberikan penulis yaitu:

1. Bagi pengarang, diharapkan dapat menciptakan karya sastra lagi terutama mengangkat unsur budaya Minangkabau yang lainnya pada karya selanjutnya.

2. Bagi pembaca, penelitian ini dapat menambah minat baca terhadap karya sastra dan dapat menangkap maksud dan amanat yang disampaikan dan mampu mengaplikasikan nilai-nilai dalam novel Mencari Cinta yang Hilang karya Abdulkarim Khiaratullah ke dalam kehidupan nyata.

3. Bagi peneliti sastra, penelitian ini dapat memperkaya wawasan sastra sehingga bermanfaat bagi perkembangan karya sastra yang ada di Indonesia dan diharapkan dapat melanjutkan penelitian mengenai unsur budaya daerah lainnya yang terdapat dalam novel-novel yang ada di Indonesia.
4. Bagi bidang ilmu pendudukan khususnya pembelajaran sastra, Jika disesuaikan dengan pembelajaran di kelas pada kurikulum 2013 hasil penelitian ini bisa digunakan untuk kelas XII dengan indikator menginterpretasi makna teks novel dalam hal ini novel Mencari Cinta yang Hilang karya Abdulkarim Khiaratullah yang menggangkat budaya Minangkabau dan juga siswa khususnya kelas XII di wilayah Sumatera Barat masih sangat butuh terhadap pengetahuan budaya dan aspek-aspek maupun pesan budaya yang bisa diteladani dalam kehidupan sehari-hari.

\section{Daftar Pustaka}

Damono, Sapardi Djoko. 1984. Sosiologi Sastra Sebuah Pengantar Ringkas. Jakarta : Pusat Pembinaan dan Pengembangan Bahasa.

Endaswara, Suwardi. 2011. Metodelogi Penelitian Sosiologi Sastra. Yogyakarta: CAPS.

Koentjaraningrat. 1992. Beberapa Pokok Antropologi Sosial. Jakarta: Dian Rakyat.

Koentjaraningrat. 1990. Pengantar Ilmu Antropologi. Jakarta: Rineke Cipta.

Koentjaraningrat. 2004. Kebudayaan Mentalitas dan Pembangunan. Jakarta: Gramedia.

Ratna, Nyoman Kutha. 2011. Antropologi Sastra Peranan Unsur-unsur Kebudayaan dalam Proses Kreatif. Yogyakarta: Pustaka Pelajar.

Semi, M. Atar. 1988. Anatomi Sastra. Padang: Angkasa Raya. 
Semi, M. Atar. 1993. Metode Penelitian Sastra. Bandung: Angkasa

Muhammad. 2011. Metode Penelitian Bahasa. Jogjakarta: Ar-Ruzz Media.
Moleong, Lexy. 2010. Metodologi Penelitian Kualitatif. Bandung: Rosda.

Navis, AA. 1986. Alam Takambang Jadi Guru. Jakarta: Grafini Press. 